\title{
The Impact of Psychological Capital and Work Meaningfulness on Work Engagement in Generation Y
}

\author{
Monica Budi Sutrisno ${ }^{1}$, Endang Parahyanti ${ }^{2}$ \\ ${ }^{1,2}$ Faculty of Psychology, University of Indonesia, Depok, Indonesia
}

Email: parahyanti@gmail.com

\begin{abstract}
Generation Ys are known as a lazy, demanding, and ungrateful generation, especially at work (Alch, 2006). Generation Ys are also seen as job-hoppers, needy, and deluded narcissistic (Gani, 2016). However, those stereotypes are not necessarily true. When asked, those young people said that they wanted to play meaningful roles and doing meaningful works (Martin, 2005). Psychological Capital (PsyCap) also expected to increase Generation Ys' engagement to their work (Luthans et al., 2006). Previous studies found that both meaningfulness and PsyCap have a significant impact on work engagement separately (Nugroho, Mujiasih, \& Prihatsanti, 2013; Jacobs, 2013) but it is still uncommon to see the effect of these two variables altogether to work engagement, especially on Generation Ys employees. Therefore, this study was conducted to see the effect of PsyCap and work meaningfulness to work engagement on Generation Ys employees. The survey was conducted to 52 participants $($ Male = 20; Female $=32$ ), across Jakarta, Tangerang, Bekasi, and Bogor, with age ranging from 20 to 27 years. Results showed that there were significant and positive correlations between all dimensions of PsyCap and work meaningfulness with all dimensions of work engagement. Together, PsyCap and work meaningfulness also can significantly give a positive impact to work engagement by $65.1 \%$. Consistently, optimism (one dimension of PsyCap) has a significant and positive impact to all of work engagement dimensions.
\end{abstract}

Keywords: generation y; psychological capital; work engagement; work meaningfulness

\section{Introduction}

Generation $\mathrm{Y}$ is a generation of workers born and growing along with rapid technological advances. There are various stereotypes about the workings and attributes of Generation Y. They are seen as lazy, demanding, and less thankful generation, especially in working (Alch, 2006). Other judgments also see Generation Y as job-hoppers, needy, and selfish (Gani, 2016). Many Generation Y's qualities of work are doubtful, one of which is the work engagement they have. Based on survey results from Gallup (Willoughby, 2011), 71\% of Generation Y employees are not engaged and tend to turn over from their work. This is far more than any other generation. Some of the reasons for this behavior are that Generation $\mathrm{Y}$ is less likely to work on jobs that are less challenging, meaningful, and improve quality of life (Berg, Dutton, \& Wrzesniewski, 2003). Taken together, it seems that Generation $\mathrm{Y}$ tends to have lower work engagement.
Schaufeli, Bakker, and Salanova (2006) defined work engagement as a state of mind filled with work-related positive things, characterized by vigor, dedication, and absorption. Vigor is a high level of energy and mental resilience when working, as well as willingness to try more in a job and persistent in the face of adversity. Dedication is a strong self-involvement in a job, feeling meaningful, enthusiastic, inspired, proud, and challenged. Absorption is an effort to concentrate fully and feel happy with work so time passes so fast and focus hard on his work. By having a high work engagement, it will prevent employees from being lazy, job hoppers, quitters, and slackers.

A study revealed that Generation $\mathrm{Y}$ employees basically want a job that gave them the opportunity to play a meaningful role and do meaningful works (Martin, 2005). Steger, Dik, and Duffy (2012) saw meaningfulness towards work not just what the meaning on the work itself, but also how the work was able to give 
significance and positive impact for employees (meaningfulness). It is not just the meaning of the work, but also how the work is able to significantly and positively impact the employee. The term "meaningfulness" is used to emphasize the importance of how confident the employee is that they work is significant or important (Rosso, Dekas, \& Wrzesniewski, 2010).

If an employee sees his work as meaningful, the employee will be increasingly motivated to give more to the job and will make him more engaging in his work. In addition, employees will also be more satisfied when their psychological needs are met through the meaning they get from work (Jacobs, 2013). Therefore, efforts should be made to make employees feel the meaningfulness of what they do so that they can become more engage and feel satisfied with their work.

The other factor that is expected to increase work engagement is Psychological capital (PsyCap) PsyCap is defined as a state of positive psychological development with characteristics: (1) having the confidence to select and exert the necessary effort to succeed in tasks (self-efficacy); (2) make positive attribution of current and future success (optimism); (3) be diligent in achieving the objectives and, when necessary, divert the means to achieve the goal in order to succeed (hope); and (4) when troubled, employee can survive and rise again even beyond the original state to succeed (resiliency). The idea of the role of PsyCap derived from positive psychology that is specifically used to maintain harmony between personal and organizational goals and work conformity (Luthans, Youssef, \& Avolio, 2007). PsyCap can serve as one of the individual resources affecting his work engagement. Building character of employees based on resources owned in PsyCap will be aligned in their development of work engagement. Employees with high levels of PsyCap will be attached and more enthusiastic with their work, or in other words, have more attachment to their work (Avey, Reichard, Luthans, \& Mhatre, 2011). Other studies have also shown results that there is an influence of PsyCap to work engagement (Simons \& Bultendach, 2013).

Based on those descriptions, this research will try to prove that work engagement on Generation $\mathrm{Y}$ can be improved through PsyCap and work meaningfulness. This research is important because there are so many stereotypes about Generation Y employees and that there is still lack of research, especially in Indonesia, which involves all three variables altogether on Generation Y employees.

There are questions that try to be answered in this research:

1. Is there any relationship between PsyCap and work meaningfulness with work engagement on Generation Y employees?

2. Is there any significant influence of PsyCap and work meaningfulness altogether with work engagement on Generation $\mathrm{Y}$ employees?

Theoretically, this research is expected to add insight in the study of work engagement in Generation Y. Practically, this research is expected to increase awareness of the importance of work engagement, PsyCap, and work meaningfulness for the effectiveness and productivity of employees, especially on Generation Y.

\section{Methods}

Sample. The sampling method used for this study was non-probability sampling with convenience sampling as the technique, based on the ease of obtaining the sample (Gravetter \& Forzano, 2012). Researchers gave online questionnaires to Generation Ys who work actively in the area of Jakarta and surrounding areas via social media (Facebook, Instagram, etc.). The characteristics of the participants were being actively employed in one company, both public and private, in Jabodetabek and acquired bachelor degree or equivalent as their level of education, with age range from 18 years to 37 years in the year of present study conducted (2017), and willing to participate in in this research. Final data collected from 52 participants: 32 were female $(61.5 \%)$ and 20 were male $(38.5 \%)$. Their education varied from bachelor degree or equal $(96.2 \%)$ and master degree $(3.8 \%)$. Most of the participants were from Jakarta, aged 23 years $(\mathrm{M}=22.96, \mathrm{SD}=1,252)$, and had working experience for about 1 year $(\mathrm{M}=$ 13.88, SD = 13.26). In addition, most participants also work in private companies and are at the staff level. The descriptive results for the participants can be seen in Table 1 . 
Table 1

Descriptive Results of Participants

\begin{tabular}{|c|c|c|}
\hline Characteristics & $\mathbf{N}$ & $\%$ \\
\hline \multicolumn{3}{|l|}{ Age } \\
\hline$<20$ & 1 & 1.9 \\
\hline $21-23$ & 39 & 75.0 \\
\hline $24-25$ & 10 & 19.2 \\
\hline$>26$ & 2 & 3.8 \\
\hline \multicolumn{3}{|l|}{ Gender } \\
\hline Male & 20 & 38.5 \\
\hline Female & 32 & 61.5 \\
\hline
\end{tabular}

\begin{tabular}{ccc}
\hline Level of Education & & \\
Bachelor Degree & 50 & 96.2 \\
Master Degree & 2 & 3.8 \\
\hline Work Experience & & \\
< 6 mths & 10 & 19.2 \\
7 - 12 mths & 30 & 57.7 \\
13 - 24 mths & 7 & 13.5 \\
25 - 36 mths & 1 & 1.9 \\
37 - 48 mths & 1 & 1.9 \\
> 48 mths & 3 & 5.8 \\
\hline Work Location & & \\
Bekasi & 2 & 3.8 \\
Bogor & 3 & 5.8 \\
West Jakarta & 12 & 23.1 \\
Central Jakarta & 7 & 13.5 \\
South Jakarta & 8 & 15.4 \\
North Jakarta & 4 & 7.7 \\
Tangerang & 16 & 30.8 \\
\hline
\end{tabular}

Research Design. This research used quantitative research method. The type of research used was survey research design, with the aim to obtain an accurate picture of the sample to be studied (Gravetter \& Forzano, 2012). Researchers used the IBM SPSS Version 20 to analyze the data and to fulfill the criterion of reliability and validity test. In addition, researchers also tested multiple regressions to see the direct effect of PsyCap and work meaningfulness altogether to work engagement.

Instrument and Measurement. The researchers used the Utrecht Work Engagement Scale (UWES-9) from Schaufeli, Bakker, and Salanova (2006) that have been adopted by Daniswara (2012) to measure work engagement. The questionnaire consisted of three dimensions, namely vigor, absorption, and dedication, and consisted of a total of nine statements. The response was given by the participants in Seven
Scale Likert Scale ranging from number 0 (Never felt that way) up to number 6 (Always feel that way). Based on the reliability test, UWES-9 obtained 0.914 for the alpha Cronbach value, which means that this questionnaire can measure work engagement consistently. The reliability for the UWES-9's dimensions also shows consistency with the value of alpha Cronbach ranging from 0.803 to 0.845 . Item-total correlation ranged from 0.661 to 0.789 . These results show that UWES-9 proved to be consistent and valid to measure work engagement.

To measure PsyCap, researchers used Psychological Capital Questionnaire (PCQ) created by Luthans, Youssef, and Avolio (2007) that have been adapted by Daniswara (2012). The questionnaire consists of four dimensions, namely self-efficacy, hope, resilience, and optimism, and responded by using Six Scale Likert Scale from number 1 (strongly disagree) to 6 (strongly agree). The reliability for PCQ also shows consistency, with 0.893 for the alpha Cronbach value with the level of validity for the items ranging from 0.208 to 0.675 . Reliability value for the four dimensions that exist in PCQ is also showing consistency, with the value of alpha Cronbach ranging from 0.645 to 0.803 . Although there are two dimensions have a value below 0.8 , the researchers did not reduce the item in it because this PCQ have previously been tested and had been deducted in the previous study. The item-total correlation value for each item is also not below 0.2 .

Researchers also adapted meaningfulness scale from Work And Meaning Inventory (WAMI) from Steger, Dik, and Duffy (2012). The questionnaire consists of ten items of statements responded by using Five Scale Likert Scale from number 1 (strongly disagree) to 5 (strongly agree). This questionnaire also has good reliability, with 0.889 for the alpha Cronbach, The item-total correlation ranged from 0.382 to 0.779 . These results show that UWES-9, PCQ, and WAMI are consistent and valid to measure each variable.

Procedure. First, researchers gather resources for the questionnaires and adapt the questionnaires to Indonesian language. After that, researchers created an online survey and spread the information link to collect data. 52 data has been collected and been analyzed to see the validity, 
reliability, correlation, and multiple regression for each variable.

\section{Results}

Before doing the correlation and regression test, the researchers looked at the distribution of data from each measuring instrument and obtained the result that the distribution of existing data is normally distributed $(\mathrm{p}>0.05)$. The total score obtained for work engagement ranged from 15 to $49(M=36.21, \mathrm{SD}=8.09)$. The score obtained for PsyCap ranged from 63 to $120(M=90.92$, SD $=11.57)$. The total score obtained for work meaningfulness ranged from 22 to $49(M=36.54$, $\mathrm{SD}=6.42)$. The descriptive statistics can be seen in Table 2.

Table 2.

Descriptive Statistics of All Variables

\begin{tabular}{llll}
\hline Variable & N & Range & Mean \pm SD \\
\hline Work Engagement & 52 & $15-49$ & $36.21 \pm 8.09$ \\
Psychological Capital & 52 & $63-120$ & $90.92 \pm 11.57$ \\
Work Meaningfulness & 52 & $22-49$ & $36.56 \pm 6.42$ \\
\hline
\end{tabular}

Next, correlation analysis was conducted. The analysis showed that there was a positive, moderate, and significant relationship of PsyCap and work engagement $(r=0.597, p<0.01)$. Positive and significant relationships were also found in the four dimensions of PsyCap with the three dimensions of work engagement. A positive and strong, and significant relationship was also found between work meaningfulness with work engagement $(\mathrm{r}=$ $0.765, \mathrm{p}<0.01$ ). Based on these results, it indicates that both PsyCap and work meaningfulness have a positive and strong relationship with work engagement which shows that when the PsyCap or work meaningfulness in the employee is high, then the work engagement owned by the employee should also be high. It will also happen vice versa. The correlation test results between variables can be seen in Table 3.

At final stage, multiple regression analysis was conducted. The results of the regression indicated the two predictors explained $65.1 \%$ of the variance $\left(\mathrm{R}^{2}=.651, \mathrm{~F}(2,51)=45.66, \mathrm{p}<0.05\right)$. It was found that PsyCap significantly predict work engagement $(\mathrm{B}=0.204, \mathrm{p}<0.05)$. Meanwhile, work meaningfulness also gives a significant effect $(B=0.784, p<0.05)$ on work engagement. The regression equation obtained from this regression test is $\mathrm{Y}=-11.003+0.204$ PsyCap +
0.784 work meaningfulness $+e$. Multiple regression test results can be seen in Table 4 .

\section{Discussion \& Conclusion}

Discussion. Based on the results of this study, it was known that there was a significant influence of PsyCap on work engagement. This is consistent with previous studies, both from Indonesia (Daniswara, 2012; Nugroho, Mujiasih, \& Prihatsanti, 2013) and United States (Hodges, 2010; Sweetman \& Luthans, 2010; Seaton, 2011). Meanwhile, work meaningfulness also known to have a positive and significant influence on work engagement. This is also in accordance with previous studies (Jacobs, 2013, van Zyl, Deacon, \& Rothmann, (2010); Geldenhuys, Laba, \& Venter, 2013).

PsyCap is one of the most positive and important resources to existing in the individual while working (Luthans et al., 2007). By building the character of Generation Y employees based on resources in the form of PsyCap, it will be in line with the development of their work engagement. Employees with high self-efficacy will increasingly believe in their ability to work and finish their tasks. Hope and optimism will also make employees have high expectations of what they are doing and what they can achieve. They also will not easily fall when faced with challenges if they have resiliency. Therefore, with the existence of these resources can help the Generation $Y$ employees to develop the characteristics needed to become more engaged in their work. Meaningfulness also is thought to have an impact on work engagement through the notion that individuals have an inherent drive to find meaning in their work. If individuals perceive their work to be personally meaningful, they are likely to be motivated to invest more of themselves and, henceforth, become more engaged in it. Conversely, if one lacks meaning in their work, they are likely to alienate themselves or become 'disengaged' from it (Jacobs, 2013).

Nevertheless, there is a weakness for this research. This research tried to see things that can improve work engagement on Generation Y in Jakarta and surrounding areas. However, this study still needs to be enriched by collecting more participants for all of the areas to widen the perspectives. Despite that weakness, this research is expected to be one of the contributions and able to inspire other 
researchers to examine more deeply the relation and the influence of PsyCap and work meaningfulness to work engagement. Future research is expected to be better able to see more specifically and maximize the data obtained (e.g. differences between sex, age group, length of service, etc.). Interviews with some respondents can also enrich the results of the study.

Conclusions. The conclusion of this research is that there were positive and significant correlations between PsyCap, work meaningfulness, and work engagement, especially in Generation Y employees. The four dimensions in PsyCap and the three dimensions in work engagement also had positive and significant correlations with each other. Results also showed that together, PsyCap and work meaningfulness could affect work engagement positively and significantly in Generation $\mathrm{Y}$ employees.

Table 3

Correlation Test Results Between Variables

\begin{tabular}{|c|c|c|c|c|c|c|c|c|c|c|}
\hline Variable & 1 & 2 & 3 & 4 & 5 & 6 & 7 & 8 & 9 & 10 \\
\hline 1.Work Engagement & 1 & & & & & & & & & \\
\hline 2.Vigor & $0.880^{* *}$ & 1 & & & & & & & & \\
\hline 3.Dedication & $0.925^{* *}$ & $0.746 * *$ & 1 & & & & & & & \\
\hline 4.Absorption & $0.891 * *$ & $0.667 * *$ & $0.725^{* *}$ & 1 & & & & & & \\
\hline 5.Psychological Capital & $0.597 * *$ & $0.604 * *$ & $0.512 * *$ & $0.509 * *$ & 1 & & & & & \\
\hline 6.Self Efficacy & $0.447 * *$ & $0.470 * *$ & $0.401 * *$ & $0.348 *$ & $0.868 * *$ & 1 & & & & \\
\hline 7.Hope & $0.559 * *$ & $0.542 * *$ & $0.507 * *$ & $0.465 * *$ & $0.844 * *$ & $0.578 * *$ & 1 & & & \\
\hline 8.Resiliency & $0.362 * *$ & $0.375^{* *}$ & $0.277 *$ & $0.339 *$ & $0.843^{* *}$ & $0.701 * *$ & $0.633 * *$ & 1 & & \\
\hline 9. Optimism & $0.619 * *$ & $0.622 * *$ & $0.507 * *$ & $0.556 * *$ & $0.706^{* *}$ & $0.491 * *$ & $0.527 * *$ & $0.404 * *$ & 1 & \\
\hline 10.Work Meaningfulness & $0.765^{* *}$ & $0.641 * *$ & $0.790 * *$ & $0.620 * *$ & $0.490 * *$ & $0.310^{*}$ & $0.536^{* *}$ & 0.257 & $0.534 * *$ & 1 \\
\hline
\end{tabular}

$\mathrm{n}=52 \quad * \mathrm{p}<0.05 \quad * * \mathrm{p}<0.01$

Table 4

Multiple Regression Test Results

\begin{tabular}{llllll}
\hline Variable & B & SE B & Beta & t & Sig. \\
\hline Psychological Capital & 0.204 & 0.068 & 0.292 & 3.017 & 0.004 \\
Work Meaningfulness & 0.786 & 0.122 & 0.622 & 6.430 & 0.000 \\
\hline
\end{tabular}

Note. $\mathrm{R}^{2}=65.1 \%(\mathrm{~N}=52, \mathrm{p}<0.05)$

\section{References}

Alch, M. L. (2006). Get Ready for The Net Generation. Training and Development Journal, 2, 32-34.

Avey, J. B., Reichard, R. J., Luthans, F., \& Mhatre, K.H. (2011). Meta-analysis of the impact of positive psychological capital on employee attitudes, behaviors, and performance. Human resources development quarterly, 22, 131-152.

Berg, J. M., Dutton, J. E., \& Wrzesniewski, A. (2013). Job crafting and meaningful work. Purpose and meaning in the workplace, 81-104.

Daniswara, A. (2012). Hubungan Antara Psychological Capital dan Work Engagement pada Perawat. Fakultas Psikologi Universitas Indonesia. 
Gani, A. (2016). Millennials at work: five stereotypes and why they are (mostly) wrong. Retrieved from https://www.theguardian.com/world/2016/mar/15/millenn ials-work-five-stereotypes-generation-y-jobs.

Geldenhuys, M., Laba, K., \& Venter, C. M. (2014). Meaningful work, work engagement and organisational commitment. SA Journal of Industrial Psychology, 40(1), 01-10.

Gravetter, F. J., \& Forzano, L. B. (2012). Research methods for the behavioral sciences. Wadsworth, Cengage Learning. International Edition: ISBN-13, 978-1.S[Lp?

Hodges, T. D. (2010). An experimental study of the impact of psychological capital on performance. engagement, and the contagion effect (Disertasi). From ProQuest Dissertations and Theses database. (UMI No. 3398191).

Jacobs, H. (2013). An examination of psychological meaningfulness, safety, and availability of the underlying mechanisms linking job features and personal characteristics to work engagement.

Kumar, R. (2011). Research methodology: A step-by-step guide for beginners $\left(3 r^{d}\right.$ ed.). London: Sage Publications, Inc.

Luthans, F., Avey, J. B., Avolio, B. J., Norman, S. M., \& Combs, G. M. (2006). Psychological capital development: toward a micro-intervention. Journal of organizational behavior, 27(3), 387-393.

Luthans, F., Youssef, C. M., \& Avolio, B. J. (2007). Psychological capital: Developing the human competitive edge. New York: Oxford University Press.

Martin, C. A. (2005). From high maintenance to high productivity: What managers need to know about Generation Y. Industrial and commercial training, 37(1), 39-44.

Nugroho, D. A. S., Mujiasih, E., \& Prihatsanti, U. (2013). Hubungan Antara Psychological Capital Dengan Work Engagement Pada Karyawan PT. Bank Mega Regional Area Semarang. Jurnal Psikologi Undip, 12(2), 192202.

Pratt, M. G., \& Ashforth, B. E. (2003). Fostering meaningfulness in working and at work. Positive organizational scholarship: Foundations of a new discipline, 309-327.
Rosso, B. D., Dekas, K. H., \& Wrzesniewski, A. (2010). On the meaning of work: A theoretical integration and review. Research in organizational behavior, 30, 91-127.

Schaufeli, W. B., Bakker, A. B., \& Salanova, M. (2006). The measurement of work engagement with a short questionnaire: A cross-national study. Educational and psychological measurement, 66(4), 701-716.

Seaton, G. A. (2011). Belonging uncertainty and psychological capital: An investigation of antecedents of the leaky pipeline in stem (Tesis). From ProQuest Dissertations and Theses database. (UMI No. 1502026).

Simons, J. C., \& Buitendach, J. H. (2013). Psychological capital, work engagement and organisational commitment amongst call centre employees in South Africa. SA Journal of Industrial Psychology, 39(2), 112.

Steger, M. F., Dik, B. J., \& Duffy, R. D. (2012). Measuring meaningful work: The work and meaning inventory (WAMI). Journal of Career Assessment, 20(3), 322337.

Strauss, W., \& Howe, N. (1991). Generations: The history of America's future, 1584 to 2069. New York, NY: William Morrow \& Company.

Tims, M., Derks, D., \& Bakker, A. B. (2016). Job crafting and its relationships with person-job fit and meaningfulness: A three-wave study. Journal of Vocational Behavior, 92, 44-53.

Van Zyl, L. E., Deacon, E., \& Rothmann, S. (2010). Towards happiness: Experiences of work-role fit, meaningfulness and work engagement of industrial/organisational psychologists in South Africa. SA Journal of Industrial Psychology, 36(1), 1-10.

Willoughby, C. M. (2011). A critical literature review exploring work engagement in the nursing profession (Dissertation). Retrieved from ProQuest Dissertations and Theses database. (UMI No. 3480027).

Wrzesniewski, A., \& Dutton, J. E. (2001). Crafting a job: Revisioning employees as active crafters of their work. Academy of management review, 26(2), 179-201. 